\title{
Lateral Thoracic Artery
}

National Cancer Institute

\section{Source}

National Cancer Institute. Lateral Thoracic Artery. NCI Thesaurus. Code C52951.

An artery arising from the axillary artery that supplies the mammary gland and chest muscles. 